\title{
ON TRANSLATING VESALIUS
}

\author{
by
}

\author{
W. F. RICHARDSON and J. B. CARMAN *
}

Andreas Vesalius's great anatomical treatise De humani corporis fabrica (1543) still awaits translation into an accessible modern language, and an English version which makes available to Latinless readers even a small part of the remarkable scholarship of this work will command much attention. The sections dealing with the larynx have been translated by D. H. Garrison and M. H. Hast, and their version was published recently in this journal. ' The present article examines their translation critically by comparing passages from it with the original Latin, and in so doing suggests that it falls some way short of fulfilling the heavy responsibility that lies upon anyone who undertakes to translate this text.

\section{A. THE TRANSLATOR'S RESPONSIBILITY}

Vesalius was both a gifted anatomist and an able Latinist. Not only is this combination of skills rarely found today, but the classicist and the anatomist now face additional problems in correctly interpreting Vesalius's account; for ancient rather than renaissance texts are still the basis for studying Latin, and there have been changes in the ways in which anatomical knowledge is acquired and presented.

Vesalius's work is famous for its detailed anatomical observation and description in Latin. Having prepared a translation into English of about one third of the text of $D e$ fabrica $^{2}$ we have no question in our minds that it thoroughly deserves its reputation. The anatomical observation and description are of the highest quality; the admixture of animal anatomy does not in any way alter this judgement. And Vesalius's use of the Latin language passes beyond competence to expertise. The presence, therefore, of clumsy, obscure and even nonsensical phrases and sentences here and there in Garrison and Hast's version is disappointing; the danger is that the reader who has no Latin and who therefore can judge the original work only by the translation may assume that these oddities and ambiguities are also in the Latin text.

The translator's prime responsibility is that of accurately representing the statements and doctrines, whether correct or erroneous, of the original author. Many elements have combined to produce the original De fabrica: they include the author's own observations,

* W. F. Richardson, PhD, Department of Classics, University of Auckland, Private Bag 92019, Auckland, New Zealand; J. B. Carman, DPhil, Department of Anatomy, University of Auckland, Private Bag 92019, Auckland, New Zealand.

' D. H. Garrison and M. H. Hast, 'Andreas Vesalius on the larynx and hyoid bone', Med. Hist., 1993, 37: 3-36. Henceforth referred to as $\mathrm{GH}$; references to their translation are by page and line (not counting headings).

2 Comprising the whole of Bk I, the captions to the remarkable series of muscle figures preceding Bk II, the first three chapters of Bk II, and isolated sections from elsewhere in the work. 


\section{W. F. Richardson and J. B. Carman}

his descriptive technique, his use of language, the illustrative drawings, and the physical details of publication. Translation introduces a further element, and it is the only one over which the original author has had no control. If the translation does not approximate to the quality of the other elements, therefore, an injustice will be done; for even a minor slip here can easily distort a careful piece of research or exposition and turn it into error or even absurdity. Such a version is not merely inaccurate; it is inevitably misleading.

Vesalius had a mastery of anatomical description which he applied to carefully observed fact. His descriptions are lucid accounts of the anatomy of humans and domestic animals. Understandably, he had not ascertained all the differences between animals and humans; for instance, he had not noted that the sympathetic chain remains independent in the neck in man and does not blend with the vagus as in domestic animals. Nor had he convinced himself that the hyoepiglottic muscles, which he claimed to have discovered ${ }^{3}$ and which are so prominent in animals, are absent in the human. But this is part of the process individuals still go through when learning comparative anatomy, a process where the first and often best learned anatomy takes precedence. Many of us are aware of a tendency to revert to firstlearned, older terminology when not on our guard. Bearing this in mind, we find very few, if any, examples of poor description of observed detail in those parts of Vesalius which we have translated, including now the parts on the larynx. Hence the appearance of a phrase in the version which is directly inconsistent with statements elsewhere in the text, or with the illustrations, or with known mammalian anatomy, must immediately call into question the translator's interpretation and English rendering of the Latin description.

Two examples will briefly illustrate these matters. One is the phrase rectos musculos illorum quattuor, discussed in more detail in passage 4 in this article. In their published versions Garrison and Hast, ${ }^{4}$ and also Saunders and O'Malley, ${ }^{5}$ find in this phrase a reference to "the four straight muscles", and Garrison and Hast have drawn attention by means of sic to the inconsistency with Vesalius's description elsewhere of only two straight muscles. ${ }^{6}$ But quattuor is indeclinable; the context must determine with which word it is taken. Vesalius has already described and illustrated four muscles joining the cricoid to the arytenoid cartilages, two straight (or, better, upright) and two oblique. Now he is using the sophisticated phrase "the upright muscles of the four" elegantly to refer to the paired posterior cricoarytenoid muscles; elsewhere he uses the complementary phrase "the oblique muscles of the four" in referring to the lateral cricoarytenoids.

The second example comes from the Epitome, Vesalius's remarkable aperçu of De fabrica. In his English version of the Epitome Lind ${ }^{7}$ chooses, in the section on the thorac spine, ${ }^{8}$ to translate suscipit as "supports" rather than "takes up" or "receives". In his version the passage reads: "[The twelfth thoracic vertebra] is supported by the adjacent vertebrae through its ascending and descending transverse processes... [and] the remaining vertebrae of the backbone above the twelfth thoracic are supported from above and in turn

\footnotetext{
${ }^{3}$ Andreas Vesalius, De humani corporis fabrica, Basle, J. Oporinus, 1543, II 33, page 229, lines 24-5 of the Latin text.

${ }^{4} \mathrm{GH}$, op. cit., note 1 above, $1818-19$.

5 J. B. Saunders and C. D. O'Malley, The illustrations from the works of Andreas Vesalius of Brussels, New York, Dover, 1973, p. 128.

${ }^{6}$ For the two (not four) posterior cricoarytenoid muscles see GH 1412.

${ }^{7}$ L. R. Lind, The epitome of Andreas Vesalius, Cambridge, Mass., MIT Press, 1969.

${ }^{8}$ Ibid., p. 4.
} 


\section{On translating Vesalius}

support those below, while those below this level are supported below and support those above them". The statement seems obtuse and confused; the point being made is hard to discern and, looked at critically, seems hardly worth making. In fact the question being addressed by Vesalius is not one of support but the way in which joint surfaces are either received by or receive their counterparts. There are lengthy discussions of this point in chapters 4, 5, and 16 of Book I of De fabrica, which refer to many joints in the body. Vesalius points out in particular that both the superior and inferior articular facets of the twelfth thoracic vertebra face somewhat outwards so that this vertebra is received by both the vertebra above and the one below, and that this distinguishes it from all others. The discussion is in terms of (the articular surface of) one bone taking up, i.e. receiving, (the articular surface of) another. In the Epitome the reference to this type of relationship is confined to the spine. The passage should read: "[The twelfth thoracic vertebra] is received by the adjacent vertebrae by means of their ascending or descending processes, the remaining vertebrae ... above this twelfth one, however, being received above and receiving below, and those below it being received below and receiving above". This is now a very worthwhile observation and reflects a clear understanding of the anatomical arrangements. Although these particular arrangements are still described, the concept of receiving is now rarely used; reference to different, more local, features now replaces the more general concept of receiving used by Vesalius as an inheritance from Galen. ${ }^{9}$

Not only are there, then, the issues of anatomical detail and Latin grammar; there remain questions which are resolvable only in terms of context. It is our experience that one should accept that Vesalius had a clear picture in his mind of what he wanted to describe ${ }^{10}$ and that his powers of description were adequate to the task. There is no place for accounting for vagueness or clumsiness in the translation by assuming Vesalius was vague about what he was saying or clumsy in his use of Latin. While he did make occasional errors of recall-for example in referring to the first instead of the second cartilage of the larynx in passage 31 below-these are, in view of the length of the whole work, surprisingly few.

The text and illustrations of De fabrica itself furnish powerful controls for the final English version, as do the facts of human and animal anatomy. This last control, of course, requires care in the handling. There is the constant issue, especially in later sections, of the misattribution of animal anatomy; and it is also most important not to read modern knowledge into Vesalius's text or to adapt the translation to fit what is now known to be the case. Yet this control is a valid one, as passage 14 below will illustrate.

Edelstein" has well described and adequately accounted for Vesalius's use of "the periodic Latin, the 'artistic prose' of Cicero". That his style is complex is undoubted; ${ }^{12}$ it is, however, logical and consistent and shows certain features which materially assist the

\footnotetext{
${ }^{9}$ Vesalius's suscipit literally translates Galen's $\dot{\pi} \pi \delta \delta \varepsilon \chi \varepsilon \tau \alpha 1$.

10 JBC writes: "Having identified the vagus unmistakably in its course through the neck in human dissection, we may presume that Vesalius assumed, but had not checked, that it gave off the sympathetic chain at the root of the neck as it does in domestic animals. Our modern-day surprise at his faulty description for the human is of the same order as my own on learning of the arrangements in domestic animals!"

"Ludwig Edelstein, Ancient medicine, Baltimore, John Hopkins University Press, 1967, p. 442.

12 The attempt to reflect this complexity in English translation is one that should be made with due caution. We have no quarrel in principle with Garrison and Hast's stated stylistic objective of "preserving some of the original character" of De fabrica; but this objective must always be subordinate to a proper understanding and rendering of the meaning of the original.
} 


\section{W. F. Richardson and J. B. Carman}

understanding. These include his use of groups of synonyms to avoid repetition or to clarify connotation and his habit of starting and ending a phrase with grammatically linked words. These aids are particularly important because his (or his printer's) use of punctuation sometimes differs from modern usage. All these points will be treated in more detail and exemplified later in this article.

We now offer, with comment, ten passages in which Garrison and Hast (hereinafter GH) have erred and hence presented to the reader a misleading view of the original; the passages are numbered for ease of reference, and appear in the order in which the reader of the translation will encounter them. ${ }^{13}$ We then proceed to discuss some of the reasons why these mistakes have been made and to indicate ways in which they may be avoided.

1. Latin 552 of index (on the connection of the hyoid to the skull): . . et ossiculis, quae his usque ad temporum ossium processus in styli modum efformatos connectuntur.

GH 5 3: “. . . and the ossicles which are connected by them to the processes of the temporal bones, shaped in the fashion of a stylus".

Comment: "Them" refers to the "sides"; ${ }^{14}$ and it is the ossicles which connect these to the styloid process, not vice versa. That Vesalius was well aware of this becomes clear a few lines later, where he refers to "the ossicles which extend to the processes that resemble a stylus". ${ }^{15}$ The error in the present passage is in the translation. His is not ablative of the instrument ("by") but dative ("to") on connectuntur "are joined"; 16 and usque ad has its usual classical meaning "all the way to" or "as far as". ${ }^{17}$ The Latin sentence is somewhat abbreviated $^{18}$ and is clearer in English if the words "and stretch" are added at the appropriate point.

Amended translation: “. . . and the ossicles which are connected to them and stretch all the way up to the styloid processes of the temporal bones".

2. Latin 5511 of text (on the hyoid bone): non desunt etiam, qui quum in faucibus consistat, id pharyngetron nuncupauere.

GH 6 8: "Moreover, there are some who, because it is located in the jaws, have called it the pharyngetron."

Comment: The hyoid bone is not located in the jaws, nor did Vesalius think it was; in fact he says in faucibus, which means "in the throat". ${ }^{19}$ His word for "jaws" is the classical

\footnotetext{
${ }^{13}$ References to the Latin text are by page and line number; thus 565 means line 5 of page 56 . Where a page contains both text and index of symbols we have referred to lines "of text" or "of index".

${ }^{14}$ For these "sides" see passage 21.

${ }^{15} \mathrm{GH}$, top of p. 6 .

${ }^{16}$ This is one of many synonyms which Vesalius has for "join": see end of section E below. A noun in the dative case is again erroneously translated as ablative (this time "from") at GH 304 , where "from these glandules" should read "to these glandules".

${ }^{17}$ Oxford Latin dictionary (henceforth OLD) s.v. usque 1.

${ }^{18}$ There is a similarly abbreviated sentence in ch. 43 of Bk II, where Vesalius writes of his 22nd muscle moving the fingers: ad summum usque pollicis apicem, secundo et tertio ossibus pertinaciter quoque adnascitur "it is attached firmly also to the second and third bones <and stretches> all the way up to the very tip of the thumb".

${ }^{19}$ Vesalius gives an extended definition of the word fauces at the beginning of Bk VI, ch. 5: it runs as follows (he is about to describe the glands in the fauces, including the tonsils). "Here, as elsewhere, we are storm-tossed on a sea of names; so let us commence the rescue process by defining fauces beyond all argument. By fauces I refer to the whole inner space bounded by the lower jaw: I mean the space which stretches in depth from the inside of the chin all the way to the cervical vertebrae and in breadth from the right side of the lower jaw to the left. I think this
} 


\section{On translating Vesalius}

maxillae, which he applies in the singular to the upper and the lower jaw. ${ }^{20}$ The Greek word corresponding to Latin fauces was pharynx, which explains the name pharyngetron quoted here.

Amended translation: "Moreover, there are some who, because it is located in the throat, have called it pharyngetron."

3. Latin 15420 (on the arytenoid cartilages): Ac harum una quidem dextro secundae cartilaginis [z] lateri, altera uero sinistro innititur, [a] sinum laeuem et alte satis caelatum obtinens, quo secundae cartilaginis tuberculum excipit.

GH 15 12: "One of these rests upon the right side of the second cartilage, the other on the left [facies articularis arytenoidea] ( $Q$ and $P$ in figures 6, 7, 8, V and $\mathrm{X}$ in figures 10,11), occupying a slight and rather deeply engraved depression, by which it accepts the tubercle of the second cartilage".

Comment: "These" refers to the two sides of the arytenoid cartilage, which means that "occupying" cannot be right. In fact obtineo is one of Vesalius's many synonyms for "possess". 21 When this correction is made in the translation the identification of the depression with the articular surface of the arytenoid cartilage becomes clear; and it would be better to delete GH's reference to the facies articularis arytenoidea of the cricoid cartilage and instead to give the modern name of the depression, as in the amended version below. GH have compounded the problems by gathering the figure references into a single group. In fact the superscript letters which refer to the marginal references to the illustrations usually precede the word to which they apply (note in the Latin text that [a] follows a comma and applies to sinum). So $Q$ and $P$ in figures 6, 7 and 8 (reference [z]) mark the two sides of the second (cricoid) cartilage, and V and $\mathrm{X}$ in figures 10 and 11 (reference [a]) the articular surfaces of the third (arytenoid) cartilage. Finally, the $a$ in laeuem represents a long e in classical Latin and thus enables Vesalius to distinguish leuis (laeuis) with a long e (meaning "smooth") from leuis with a short e (meaning "light", "slight"); ${ }^{22}$ so the inconsistency between "slight" and "rather deeply engraved" in GH's version is not Vesalius's.

\footnotetext{
is what the ancient Greeks called the pharynx, under which name they included the larynx, which is contained within this area: they did not observe the distinction of Suidas, which applies the word pharynx with masculine gender to the larynx and with feminine gender to the fauces. They seem to have applied the name isthmos to the same area, because in the whole body there is no region which is both as narrow and contains as many organs. In this area the nasal foramina come down into the mouth, and here reposes the whole larynx, the beginning of the oesophagus, the root of the tongue and the hyoid bone, together with the numerous muscles belonging to those parts and the muscles moving the jaw, both those which originate from the pterygoid processes of the sphenoid bone and those which have two bellies (mainly because of the narrowness of this area) and which draw the lower jaw downwards. Add to these certain offshoots of the third, sixth and seventh pairs of cerebral nerves, the jugular veins, the carotid arteries and the glands to whose description I now thankfully turn."

20) Vesalius, op. cit., note 3 above, Bk I, chs 9 and 10.

21 Compare OLD s.v. 7b and 8. Others include nanciscor (Vesalius, op. cit., note 3 above 25813 ), sortior (68 26), habeo (64 37), ostendo (64 39), obtingo (65 4); also the dative of possession (66 19) and the phrase sibi uindico (always spelt uendico; e.g. 68 24).

22 So in Bk I Vesalius frequently refers to the smooth and slippery cartilage (cartilago laeuis et lubrica: 4 13) which is smeared over bone joints to reduce wear and tear $(43)$. Compare also caeterum for ceterum (first e long). But the spelling convention is not consistently applied; at 15343 leuis (spelt thus) means "smooth" (correctly so translated by GH at 149 ), and at 2158 appears the word compraehendimus, where ae represents a short e. At 1223 laeuiori is actually leuiori "lighter".
} 


\section{W. F. Richardson and J. B. Carman}

Amended translation: "One of these rests upon the right side of the second cartilage, the other on the left ( $Q$ and $P$ in figures 6,7, 8); each possesses a smooth and rather deeply engraved depression [articular surface of arytenoid cartilage] ( $V$ and $X$ in figures 10, 11), by which it accepts the tubercle of the second cartilage".

4. Latin 25710 (on the cricoarytenoid muscles as depicted in figures 7 and 8): Octaua a septima in hoc differt, quod hic rectos musculos illorum quatuor, qui tertiam cartilaginem secundae nectunt, rescidimus.

GH 18 18: "The eighth differs from the seventh in this way, that here we have cut back the four [sic] straight muscles of those that bind the third cartilage to the second".

Comment: Vesalius recognizes four muscles binding the third cartilage to the second (they are intrinsic muscles 5-8: GH 23), of which two proceed "straight up" and are therefore recti, and two diagonally and are therefore obliqui. ${ }^{23}$ The error whereby Vesalius seems to refer in the present passage to four instead of two "straight up" muscles is (as we have indicated above) merely one of translation. Quatuor is indeclinable and may function as any case; GH have taken it as accusative plural with musculos whereas in fact it is genitive plural with illorum: "the straight-up muscles of the four that...". The sic is therefore unnecessary and can go. The same error is made on p. 18 in the description of the ninth figure (line 23), where GH's “. . . the four [sic] oblique muscles ..." should read ". . . the oblique muscles of the four ...".

Amended translation: "The eighth differs from the seventh in this way, that here we have cut back the upright muscles of the four that bind the third cartilage to the second".

5. Latin 25718 (on a superior view of the larynx): Exprimitur itaque hic larynx, a reliquo asperae arteriae trunco, et suis communibus musculis libera, quae asseruato adhuc ipsius operculo, posteriori suae sedi incumbit, superioremque faciem commonstrat.

GH 18 33: "Therefore the larynx is drawn here free from the remaining trunk of the rough artery and from its common muscles; its operculum is still preserved, it rests on its posterior [sic; anterior] surface, and it shows its superior [sic; posterior] surface."

Comment: The supposed errors to which GH draw attention here by sic are again errors of translation. The relative pronoun quae is subject of incumbit and commonstrat, and its gender shows that its antecedent is larynx. ${ }^{24}$ It is therefore the larynx, not the operculum, to which the last part of this sentence refers and which in the illustration is resting on its posterior surface and showing its superior surface, as Vesalius correctly describes.

Amended translation: "Therefore the larynx is drawn here free from the remaining trunk of the rough artery and from its common muscles; the larynx, with its operculum still intact, rests on its posterior surface and shows its superior surface."

\footnotetext{
${ }^{23}$ The third member of this trio of words is transuersus "straight across" (i.e. "horizontal"). Transuersus is at right angles to rectus (and vice versa), and obliquus lies in between. In ch. 31 of Bk II Vesalius writes of the recti abdominis muscles: Rectorum ab utroque latere unicus est, qui quum fibras secundum corporis longitudinem extensas obtineat, rectus nuncupatur "there is one rectus muscle on either side; it is called rectus because its fibres lie longitudinally in the body". This succinctly defines the basic meaning of rectus in De fabrica.

${ }^{24}$ Larynx is feminine in De fabrica, though in ancient Greek it was masculine.
} 


\section{On translating Vesalius}

6. Latin 2589 of text (on the actions of the larynx): Quando itaque ex pluribus cartilaginibus larynx, ut apte clauderetur, aperireturque, constructa est, et quia spiritus, retentionis uocisque occasione, motu uoluntario, et ex nostro pendente impetu moueri eam oportet, merito musculos cartilaginum motores Natura ipsi communicauit ...

GH 22 6: "Since, therefore, the larynx is constructed from several cartilages so that it may be tightly closed and opened, and because the breath, when it is held and when we speak, ought to move [the glottis] by voluntary motion, and from our interrupted flow of air, Nature justly imparted to the larynx the motor muscles of the cartilages ..."

Comment: The strange concept that "the breath . . ought to move [the glottis] by voluntary motion" is due, not to Vesalius, but to a mistranslation of a difficult sentence. The difficulty is compounded by the misleading comma after spiritus, which makes this word look as though it were the subject of something. If this comma is ignored, spiritus immediately stands revealed as genitive singular, an objective genitive with retentionis; the four words spiritus retentionis uocisque occasione form a phrase meaning literally "for the purpose of holding the breath and of the voice". The rest of the grammar then falls into place without too much difficulty. Eam (which refers back to larynx) is the subject of moueri. Pendente goes with motu and governs ex nostro impetu; the whole phrase ex nostro pendente impetu "dependent on our own impulse" is equivalent in meaning to uoluntario. Even in classical Latin moueri could mean "to move" (active intransitive) as well as "to be moved" (passive), and we have preferred the former rendering. ${ }^{25}$ If apte goes with both clauderetur "be closed" and aperiretur "be opened" it perhaps means "appropriately", "as required" rather than "tightly".

Amended translation: "Since, therefore, the larynx has been constructed of several cartilages so that it might be closed and opened as required, and because it is necessary that it move by voluntary motion depending on our own impulse for the purpose of holding the breath or of making vocal sounds, Nature justly imparted to it the motor muscles of the cartilages..."

7. Latin 26020 (on muscles from hyoid to epiglottis): non enim (quod forte quis arbitraretur) in communium laryngis musculorum numerum sunt reiiciendi

GH 26 12: “. . . for one would assuredly not think they should be omitted from the number of the common muscles of the larynx."

\footnotetext{
${ }^{25}$ In his use of the passive infinitive moueri Vesalius reflects Aristotle's twofold use in his treatise On the movement of animals of Kivદi $\sigma \theta \alpha \mathrm{l}$ as either passive "to be moved" or middle "to move"; for the middle use compare 700a 8-9, where $\kappa \imath v \varepsilon \hat{\imath} \sigma \theta \alpha \mathrm{l}$ "to move" is directly contrasted with

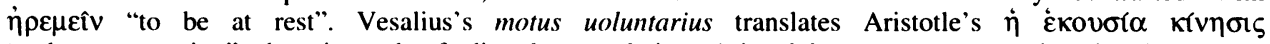
"voluntary motion"; but instead of directly translating Aristotle's cognate accusative in the phrase

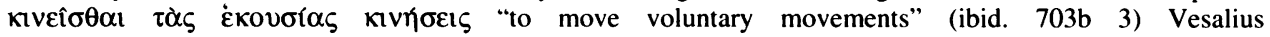
uses the ablative of means and writes moueri motu uoluntario "to move by voluntary motion". The

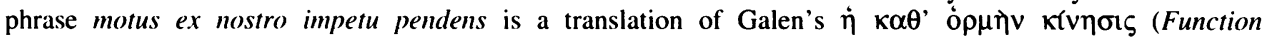
I 17). Cicero represents the concept of voluntary motion by means of the phrase per se et sua sponte moueri "to move of itself and voluntarily" (On the nature of the gods II 31), where the middle (i.e. active intransitive or, less correctly, deponent) use of moueri seems clear. Vesalius makes frequent use of the passive forms of moueo in Bk II, which describes the movement of limbs and muscles; the phrase motu uoluntario moueri appears e.g. in ch. 11 of that book, where he writes (of the eyes): si eos moueri motu uoluntario oportebat, ipsis quoque musculos largiri necessum fuit "if it was essential that they move by voluntary motion, it was necessary for them too to be supplied with muscles" (240 7 of text). The language is reminiscent of a passage in which Cicero makes reference to Aristotle's opinion "that the sun, the moon and all the stars move" (moueri
} 


\section{W. F. Richardson and J. B. Carman}

Comment: Here GH have made Vesalius say exactly the opposite of what he actually said. Even in renaissance Latin in + accusative cannot mean "from"; so here in numerum must mean, not "from the number" (as GH), but "into the number". It follows that reiicere must, despite the English derivative "reject", carry the notion of referral which it could have even in classical Latin and which it shows elsewhere in De fabrica. ${ }^{26}$ The reason why some might think that these two muscles should be assigned to the category of the common muscles is that they would make up the difference between the eight common muscles of the larynx to which Galen refers and the six which he actually describes. But, says Vesalius, these are not to be assigned to the category of Galen's common muscles, for Galen said that all eight of them are joined to the first cartilage, whereas these two are not.

Amended translation: “. . for they are not (as someone might perhaps think) to be assigned to the number of the common muscles of the larynx."

8. Latin 2614 (on the actions of the extrinsic muscles): licebit modo sex horum musculorum, laryngi communium actionem discere . . .

GH 27 28: "It will be possible to learn the action of just six of these common muscles of the larynx ...."

Comment: Vesalius has just pointed out at some length that (pace Galen) there are only six common muscles of the larynx; so "six of these common muscles of the larynx" is not correct. The error is one of translation. Horum musculorum is not partitive genitive depending on sex; it is subjective genitive with actionem ("the action of these muscles"), and sex, like quatuor in passage 4 above, is genitive plural and goes with musculorum ("the action of these six muscles"). Modo goes with licebit and, as elsewhere in De fabrica, means "now" or "next". 27

Amended translation: "It will now be possible to learn the action of these six common muscles of the larynx ..."

9. Latin 2616 (on the hyoepiglottic ligament): ... ad duos, quos operculi laryngis radici implantari dictum est, sectionem conferes.

GH 27 30: “. . . you will concentrate your dissection on the two muscles [ligamentum thyroepiglotticum] which it is said are implanted at the root of the operculum of the larynx."

Comment: Here a mishandled verb tense has led to a misidentification. Dictum est is perfect tense ("it was said"), not present ("it is said"); it is one of Vesalius's many methods

\footnotetext{
... solem et lunam et sidera omnia: De natura deorum II 44), and goes on to describe this movement as "voluntary motion" (motus uoluntarius).

${ }^{26}$ For Vesalius the verbs reiicere and reponere are synonymous in the meaning "to assign to/place in". The phrase ad classem reiicere and in classem reponere both mean "to assign to a class/category": for the former see 21725 and for the latter 257 (357) 28. For reicio="refer" in classical Latin see OLD s.v. 10. Compare also Vesalius's phrase in tabellam reiiciam "I shall assign (it) to a diagram" at 128.

${ }^{27}$ The temporal use of a single modo with a past tense verb is common in classical Latin (see OLD s.v. modo 5a); with future tense it is rare but is attested in Plautus and Terence (see OLD s.v. 5c). In De fabrica the use with future tense ("now", "next") is not uncommon; it appears again at 261 13, where GH have correctly translated modo ... adimes as "now . . you will remove" (GH 28 9). In De fabrica the word is a member of a cell meaning "now" or "next" which includes the words iam, deinde, deinceps, modo, mox, postmodum, insuper and perhaps postremo. Most of these words appear in this meaning on pp. 156-7 of the Latin text. The temporal modo does not have to be the first word in the sentence: compare 22430 (and postmodum at 2249 ).
} 
of referring back to something he has already described. ${ }^{28}$ In this instance the reference is back to the section headed Two Muscles of the Operculum of the Larynx on p. 26 of GH's version; there the "muscles" were said by Vesalius to originate from the hyoid bone, and were therefore identified by $\mathrm{GH}$ as ligamentum hyoepiglotticum. ${ }^{29}$ The same identification should be made here, especially as Vesalius goes on in the next section to trace these "muscles" once again to the hyoid bone.

Amended translation: "... you will concentrate your dissection on the two muscles [hyoepiglottic ligament] which were described as being implanted into the root of the operculum of the larynx."

10. Latin 327 (427) 23 of ch. 9 (on the vagus nerve): Praeter hanc propaginem sexti paris neruus iuxta superiorem thoracis sedem ramulos musculo offert, a pectoris osse et clauicula ad mamillarem capitis processum deducto, et capitis motibus subseruienti. Deinde et musculo qui os $v$ referens hinc a pectore accedit. Praeterea et illi qui hinc ad infimam primae cartilaginis laryngis sedem perfertur.

GH 32 31: "Besides this branch of the sixth pair, the nerve next to the superior seat of the thorax presents little branches to the muscle leading from the pectoral bone and clavicle to the mammilate process of the head, which assists the motions of the head. Next, it goes to the muscle that runs from the chest to the hyoid bone. In addition, there are those [nervi laryngeales recurrentes] that are brought from here to the lower seat of the first cartilage of the larynx."

Comment: The reference to the recurrent laryngeal nerves which GH have found within this passage is not there at all; they have misunderstood and so mistranslated the Latin. Specifically, they have taken illi as nominative plural when in fact it is dative singular. The punctuation of the original Latin with full stops before Deinde and Praeterea has obscured the fact that this is a list of the entities to which this nerve sends branches: offert governs two nouns in the dative case (musculo... musculo) and also the dative singular pronoun illi (which must be singular as it is antecedent of qui, subject of perfertur). Deinde et and Praeterea et both mean "and also". So the three entities are the sternocleidomastoid muscle, the sternohyoid muscle and the sternothyroid muscle (not the recurrent laryngeal nerves).

Amended translation: "Besides this branch, the nerve of the sixth pair next to the top of the thorax presents little branches to the muscle leading from the pectoral bone and clavicle to the mammilate process of the head, which assists the motions of the head; also to the muscle that runs from the chest to the hyoid bone; also to that which goes from here to the bottom of the first cartilage of the larynx [sternothyroid muscle]."

The ten passages reveal how minor slips in translation can have major repercussions in misrepresenting the original. The rest of this article will deal with certain matters which will help to eliminate such slips, with illustrations once again from GH's translation.

\footnotetext{
28 Others on the same page of the Latin text are quemadmodum nuper dixi "as I said a while ago", quam dixi and quam diximus "which I/we spoke of", and quos interdum obseruari dicebam "which I said were sometimes observed".

${ }_{29}$ Misspelt hypoepiglotticum here in $\mathrm{GH}$ and at 184 ; but hyoepiglotticum is correctly given on p. 20 : see $\mathrm{K}$.
} 


\section{B. THE PRINTED TEXT}

It is convenient to start with the physical aspect: the printed text itself. The facsimile edition from which GH (and the present writers) work is beautifully clear, and there is never any doubt about the reading of the original. There are, however, misprints, and the reader must be alerted to the presence of a list of errata on p. 664 of the original volume. This list solves one passage which $\mathrm{GH}$ found difficult.

11. Latin 257 A (on the hyoid bone): In prima, 2 et 3 figuris hyoidis notatur os, non prorsus suis membranulis liberum.

GH 20 A: "In the first, second and third figures is marked the face [corpus] of the hyoid, not altogether free from its own small membranes."

Comment: Vesalius does not refer to the corpus of the hyoid bone as its face. The list of errata reveals that hyoidis here is a misprint for hyoides (though unfortunately the printer makes another error in the list itself and gives the reference as 2572 instead of 257 24). Hyoides is nominative singular neuter agreeing with os ="bone".

Amended translation: "In the first, second and third figures is marked the hyoid bone, not altogether free from its own small membranes."

The list of errata also reveals a huge error in the page numbering of the original volume. The numbering is correct (apart from an occasional misprint ${ }^{30}$ from pp. 1-312; page 312 is followed by p. 213, and this error is carried on to the page headed 391 (actually 491), which is followed by a page correctly headed 492 . Apart from an occasional misprint, ${ }^{31}$ the numbering is correct thereafter. To avoid confusion we have referred to the misnumbered pages with the correct number in brackets, thus: 285 (385).

There is one other point about the printing which requires care in reading. Instead of the letter s the printer very frequently (but not always) uses the long s, which looks like our letter $f$ with the right-hand half of the horizontal stroke missing. This is very easily misread as $\mathrm{f}$; $\mathrm{GH}$ have done so at least once. ${ }^{32}$

\section{PUNCTUATION}

Passages 6 and 10 above have shown that the punctuation system of the Latin text is not always the same as our modern system, and the modern reader of the Latin must take care not to be misled by it. A comma sometimes appears where there is no actual grammatical break in the sentence, as in passage 6 above; and GH have been trapped by a similarly intrusive comma in the following passage.

12. Latin 26012 (on the sternothyroid muscles): Verum his contrariam functionem adipiscuntur musculi, a pectoris osse, primae cartilagini inserti, illi nanque humiliores, primae cartilaginis sedes contrahunt, easdemque deorsum uellunt, nonnihil una contrahentes stringentesque asperam arteriam.

GH 26 1: "The muscles from the pectoral bone inserted in the first cartilage achieve the opposite function; for these lower muscles contract the seats of the first cartilage and

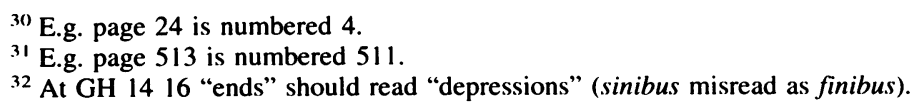


turn them downward, at the same time somewhat contracting and tightening the rough artery".

Comment: "The seats of the first cartilage" is a meaningless phrase in this context; it is necessary that the seats (= parts, areas) be specified. In the Latin text they are specified by means of the adjective humiliores "lower"; but the comma which follows humiliores in the text creates the illusion that it goes with illi, and this is how GH have mistakenly tried to take it. Vesalius has previously said that these muscles (and the thyrohyoid muscles) are inserted into the lower area of the thyroid cartilage: see GH 2520 "lower seat" and 2530 "that seat of the first cartilage which we mentioned".

Amended translation: "The muscles which come from the breast bone and are inserted into the first cartilage have the opposite function to these; for they draw together the lower areas of the first cartilage and pull them downward, at the same time somewhat contracting and narrowing the rough artery".

Intrusive commas often precede a co-ordinating conjunction ("and", "but", "or") and may, again, cause problems for the modern reader if there is no actual grammatical break at that point. At 26146 of the original Latin appears the phrase exiguo, sed acutiori cultello; and $\mathrm{GH}$, realizing that the comma here must be ignored, have quite properly translated this "with a small but sharp knife" (29 21). But they have been misled by a similar use of the comma in other places, as exemplified in the two following passages.

13. Latin 15446 (on the glottis): Plerique corpus hoc praecipuum uocis organum esse putarunt, id temere $\gamma \lambda \omega \tau \tau \hat{\imath} \delta \alpha$ et $\dot{\varepsilon} \pi \hat{\imath} \gamma \omega \tau \tau \hat{\imath} \delta \alpha$ uocitantes: quum tamen haec nomina penitus pugnantes, diuersasque prorsus partes, ueteribus illis Anatomes professoribus significauerint.

GH 16 11: "Most have thought that this is the especial organ of the voice, terming it haphazardly glottis and epiglottis; but these names are completely contradictory and they signified completely different parts to the ancient professors of anatomy."

Comment: To say that the names "glottis" and "epiglottis" are "completely contradictory" is a considerable overstatement; and in fact Vesalius has been made to say this by a misunderstanding of both the grammar and the meaning of pugnantes. The grammar of the word shows that it must describe partes "parts", not nomina "names"; and although in classical Latin it meant "contradictory" ${ }^{33}$ its meaning had by Vesalius's time weakened to just "different", so that here it is synonymous with diuersas. ${ }^{34}$ Hence the noun partes is defined here by two synonymous phrases penitus pugnantes "completely different" and diuersas prorsus "quite distinct". The phrases are joined by "and" (-que), and the comma following pugnantes is the comma which, in this text, often precedes "and", and which may, as here, deceive the modern reader into thinking that there is some sort of grammatical break at this point.

Amended translation: "Most have thought that this is the especial organ of the voice, haphazardly terming it glottis and epiglottis; but these names signified completely different and quite distinct parts to the ancient professors of anatomy."

\footnotetext{
${ }^{3.3}$ Compare OLD s.v. pugno 6.

${ }^{34}$ In ch. 27 of $\mathrm{Bk} \mathrm{I}$ it is similarly synonymous with uarias: there uarias pugnantesque means "varied and different". For such pairs of synonyms see section $F$ of this article.
} 


\section{W. F. Richardson and J. B. Carman}

14. Latin 15330 of text (on the cricothyroid articulation): Inferiores autem scutiformis cartilaginis processus, lateribus secundae cartilaginis uersus posteriorem ipsius sedem uniuntur, coalescuntque.

GH 13 26: "The lower processes of the shieldlike cartilage are united to the sides of the second cartilage towards its posterior seat, and join together."

Comment: The lower processes of the thyroid cartilage do not join together, nor was Vesalius under the impression that they do. Uniuntur coalescuntque is another example of two synonyms joined by "and". The comma after uniuntur is due to the "and"; there is no grammatical break, and lateribus "to the sides" goes with both synonyms.

Amended translation: "The lower processes of the shieldlike cartilage are joined and united to the sides of the second cartilage towards the back."

\section{VESALIUS'S LATIN STYLE}

All writers write in their own way; that is, they have their own characteristic style. Their grammar is that of the language in which they are writing (and some will handle it better than others); but apart from grammar their writing shows various features which add up to a style that is uniquely their own.

Vesalius's grammar is that of classical Latin as extended and modified after the classical period. ${ }^{35}$ Its rules are for the most part scrupulously obeyed: in the 222 pages (some 120,000 words) through which we have worked, we have noted only half a dozen instances of suspect grammar. This is an achievement by Vesalius at which a modern classicist might well gasp in awe. And it has an important consequence for the translator: the discovery of what may seem like a grammatical error in the Latin must throw suspicion in the first instance, not on Vesalius's grammar, but on the translator's understanding of the sentence. Vesalius was well aware that pugnantes cannot possibly agree with nomina (see passage 13 above).

The grammar can be learned from books; familiarity with the style can only come from experience. The translator who commences work on De fabrica must start by undergoing a learning process which is largely one of becoming familiar with the characteristic features of Vesalius's Latin style. Then and only then, having learned how the author writes, the translator must go back to the beginning of the text, applying to it the knowledge which was gained from the first run through. He, or she, will certainly find that passages which were unclear before now become clear in the light of the new found knowledge. It is those who have not read enough of Vesalius's Latin to become familiar with his style who charge him with obscurity; when sufficient stylistic knowledge has been gained, the supposed difficulty largely vanishes.

It is one of the chief aims of this article to document certain characteristic features of Vesalius's Latin style and thus to shorten the time which must be given to the learning process. The points made in the following sections are reinforced by means of passages from GH's translation as before.

\footnotetext{
${ }^{35}$ The extensions are mainly in the field of word usage. The classicist is interested to find quousque for "until" (sometimes with a preparatory tantisper in the main clause: 329 (429) 1-2, ilico atque and mox ubi for "as soon as" (217 1; 1584 ), and inter+accusative of the gerund for "in the course of (doing something)" (154 54: inter edendum "in the course of eating"; compare GH 1622 ). Compare also the passages in section $\mathrm{H}$ of this article.
} 


\section{On translating Vesalius}

\section{E. VARIETY AND THE USE OF SYNONYMS}

This feature of Vesalius's style is well illustrated by a sentence from Book I chapter 4 (11 40): Quinetiam ossa inuicem componuntur non solum motus gratia, sed etiam alicuius corporis transitus occasione, aut securitatis, seu noxiis ferendis pertinaciae causa, aut partium diuersitatis nomine "Bones are joined together, not only for the sake of movement, but also to allow something to pass through, or for the sake of security or resistance to injury, or because of a difference between parts". Here we find Vesalius using four different words meaning "for the sake of": gratia, occasione, causa and nomine. Of these, two are used by classical authors in this meaning (causa and gratia) and two are not (occasione and nomine). We shall, for the sake of convenience, refer to such a group as a cell. The discovery that occasione and nomine belong in this cell is part of the learning process referred to earlier, and will help the translator with the translation of these words in contexts where their relationship to classical causa and gratia is not so obvious.

Vesalius has many such cells, which he uses for variety and to avoid constant repetition of one or more words. One such cell contains verbs equivalent in meaning to the verb "to be" (esse). This cell includes existere and the passive of various verbs meaning "see": uisitur "is seen (to be)" means simply "is". Because classical uidetur "is seen" also means "seem", "appear" ${ }^{\text {"36 }}$ there is a temptation to give uisitur and others in this text the same meaning; but in De fabrica they mean "is", with no implication that something only seems to be the case and is not actually so. This affects the following passages of GH's translation.

15. Latin 56 14-15 (on the lesser horn of the hyoid): . . quod magis teres uisitur ... GH 9 4: "which appears smoother".

Comment: The Latin adjective teres refers to the rounded sides of a cylinder and contrasts them with the angular edges of a rectangular block. ${ }^{37}$ Vesalius is making the point that the side-bones are a different shape from the main bone: their sides are rounded in a way its sides are not. He does not suggest that this roundedness is only apparent: uisitur means "is seen (to be)" and therefore "is". Similarly at GH 1424 "appears quite thin" renders Latin nonnihil tenuis uisitur (1542) and should read "is quite thin"; and at GH 2519 "(they) seem contiguous” renders Latin contigui uisuntur and should read "(they) are contiguous". The translator is not confined to the literal rendering "is seen" in translating uisitur: it had been used in Latin to mean "exists" since the fourth century AD. ${ }^{38}$

Amended translation: "which is more rounded".

16. Latin 15331 of text (on the thyroid cartilage): Scutiformis haec cartilago uiris quam mulieribus antrorsum magis prominet, tactuique magis exponitur: et subinde gemina, idque potissimum in uiris obseruatur.

GH 13 28: "This shieldlike cartilage juts out more towards the front in men than in women, and is more exposed to the touch; and now and then, it is a twin, and it is especially observed in males."

\footnotetext{
${ }^{36}$ OLD s.v. uideo 20.

${ }^{37}$ OLD s.v. 1. The geometrical form known to us as a cylinder is expressed in ch. 27 of Bk I by means of the phrase teres corpus "rounded (cylindrical) body" (123 19 and 25).

${ }^{38}$ For uisitur = "exists" see C. T. Lewis, and C. Short, A Latin dictionary, Oxford, Clarendon Press, 1879 and many subsequent reprints, s.v. viso I ad fin.
} 


\section{W. F. Richardson and J. B. Carman}

Comment: The vague repetitiousness of "it is especially observed in males" is not in the Latin; it has come about through a failure to realize that obseruatur, like uisitur, means "is seen to be" and so "is", and that gemina goes with it. A balancing comma after the second uiris would have made things clearer.

Amended translation: "This shieldlike cartilage juts out more towards the front and is more exposed to the touch in men than in women; often it is double, and that especially in males."

We add one more example of these cells. A single sentence on p. 258 of the Latin text (lines 13-16) uses four different words for "join": iungo, connecto, copulo and coarticulor, and these are by no means the only members of this cell (there are two others in passage 14 above). ${ }^{39}$

\section{F. SYNONYMOUS PAIRS}

Vesalius is very fond of using pairs of synonyms joined by "and" or "or". There is a simple example at the end of chapter 13 of Book I (56 33), where he says that certain muscles lie under the tongue fundamenti tutissimaeque basis modo "like a foundation and secure base". A foundation is a secure base: the most important thing to remember about this usage is that in it one and one make one, not two, for the two expressions both refer to the same thing. The paired words need not be nouns; they may be adverbs (as when he describes a shallow depression as leuiter et superficietenus exculptus "lightly and superficially engraved" into a bone: 14 9-10), or adjectives (as when he describes certain sockets as being rotundi orbicularesque "rounded and spherical": 10 50), or verbs (as when he says that certain bony protuberances eminent et extuberant "jut and swell out": 9 18) and so on. Despite the fact that "and" appears in all these examples, "or" is almost equally common (as when he says of certain other bony protuberances obscuro tubere gibboue praedita sunt "they have been endowed with a slight swelling or bump": 9 18). There are examples like these on almost every page of the Latin text.

Vesalius frequently uses this device as a way of explaining an unfamiliar term in his text. This may be a rare Latin adverb such as decussatim (as when he invites the reader to place the index and middle fingers instar X aut decussatim "like an X or crosswise": 13 12 ), or a Latin technical term such as synciput (as when he says that the anterior eminence of the skull stands a syncipite frontisue elatiori sede "at the sinciput or the top of the forehead": 19 23), or a Greek word (as when he says that one of the muscles originating from the zygoma is masseter siue mansorius musculus "the masseter or chewing muscle": 3324 of text). For a similar reason such collocations sometimes instruct us as to the meaning of a word in Vesalius's time; thus we learn that sedes can mean "part" (partem seu sedem 1553 ) and simus "concave" (cauum simumque 15443 ).

When this usage is extended from words to phrases the translator must proceed with especial caution. In chapter 6 of Book I (32 3) Vesalius says that the sphenoid bone is thin but very solid ad latera et in temporum cauis "at the sides and in the hollows of the temples". These are not two places but one: the two prepositional phrases, though not

\footnotetext{
${ }^{39}$ Another large cell contains words meaning "show" or "depict". In describing the contents of the eleven illustrations preceding ch. 15 of Bk I Vesalius uses the following members of this cell (61 1ff): exprimo, propono, oculis subicio, exhibeo, commonstro, designo, spectandum offero, ostendo, depictum cernitur.
} 


\section{On translating Vesalius}

strictly synonymous, are equivalent in that they refer to the same thing. In the sentence quoted at the beginning of section $\mathrm{E}$ above, an equivalent noun and phrase were paired in much the same way: securitatis seu noxiis ferendis pertinaciae "(for the sake) of security or resistance to injury". In the following passage two long phrases are similarly joined.

17. Latin 15439 (on the epiglottis): hinc introrsum procedens, trianguli imaginem exprimit, cuius basim operculi a scutiformi cartilagine exortus, aut ipsius cum ea cartilagine connexus efformat.

GH 16 2: "proceeding hence inwards, it has a triangular appearance, the base of the operculum rising from the scutiform cartilage, or it forms its own triangular shape when connected with that cartilage."

Comment: Vesalius's description of the epiglottis is not as obscurely expressed as the translation might suggest. The two paired phrases are operculi a scutiformi cartilagine exortus "the origin of the lid from the shield-like cartilage" and ipsius cum ea cartilagine connexus "its connexion with that cartilage", which refer to the same thing and are linked by aut "or". It then becomes clear that the two nouns exortus and connexus are both subjects of efformat, which governs basim as its direct object; also that basim governs cuius, whose antecedent is trianguli.

Amended translation: "proceeding hence inwards it takes on the shape of a triangle whose base is formed by the origin of the lid from the shield-like cartilage or its connexion with that cartilage."

The tendency of this text to place a comma before a co-ordinating conjunction regardless of the context means that these synonymous pairs are sometimes sundered by a comma and are then especially in danger of being mistranslated. This point has been illustrated above (see section $\mathrm{C}$ ).

\section{G. PHRASING}

Vesalius's writing is tidy and logical, and this is reflected in a liking for phrases whose beginning and end are clearly marked by words which grammatically go together. The words may be an adjective and its noun, as in this example from chapter 3 of Book I: uarius illarum apud alios et eundem subinde authorem usus "their inconsistent usage in various authors and often within the one author" (uarius with usus, 71 ); or a noun and its adjective, as in this example from the same chapter: ossa sinibus quibus medulla ossuosis fibris non intertexta continetur carentia "bones which do not have cavities containing marrow not interwoven with osseous fibres" (carentia with ossa, 740 ); or a preposition and the noun it governs, as in this example from the same chapter again: in trium tarsi ossium cum osse cymbam referente connexu "in the joint of the three tarsal bones with the bone resembling a skiff" (in governs connexu, 913 ). The translator must be sure to read on far enough to find the word that ends the phrase, otherwise disaster may follow. The following examples illustrate such phrases.

18. Latin 5515 of text (on the body of the hyoid): . . superius quasi in oblongum sinum deprimitur, pro figurae nimirum ipsi idoneae, et musculorum ligamentorumque illi commissorum ratione. 


\section{W. F. Richardson and J. B. Carman}

GH 8 7: “. . . it is indented on top as in an elongated depression, for a shape evidently suitable to it, and because of muscles and ligaments attached to it."

Comment: There is here a long phrase beginning with pro and ending with the noun it governs, ratione; pro ratione means "by reason (of)", "because (of)" and ratione governs the genitives figurae, musculorum and ligamentorum. The comma after idoneae is merely because the next word is et "and", and does not mark a grammatical break.

Amended translation: "... it is indented on top forming a sort of elongated depression, both because such a shape is appropriate for it and because of the muscles and ligaments attached to it."

19. Latin 2562 of index: una cum anteriori laryngis, et asperae arteriae caudicis (qui in collo consistit) sede.

GH 17 18: "... together with the front of the larynx and the seat of the stem of the rough artery (which is in the neck)".

Comment: "The seat of the stem of the rough artery" is a nebulous concept which does not appear in the Latin. In fact, the preposition cum governs sede, with which the adjective anteriori agrees. So the first two words of this phrase both go with the noun that closes it: cum anteriori sede means "with the front" and governs the two genitives laryngis and caudicis. The comma before et "and" again introduces into the phrase a division which to the modern reader is misleading.

Amended translation: “. . . together with the front of the larynx and the front of the stem of the rough artery (which is in the neck)".

20. Latin $258 \mathrm{C}$ (on the glottis): Lingulae seu rimae, in medio laryngis obuiae superior sedes, in decima figura conspicitur.

GH 21 c: "The upper surface of the lingula or fissure in the middle of the exposed larynx, is seen in the tenth figure."

Comment: Superior sedes "the top" has dependent upon it a phrase beginning with the synonymous pair lingulae seu rimae and ending with the adjective that agrees with (either of) them, obuiae "occurring", "found" ${ }^{40}$ Again the comma after rimae is distracting to the modern eye.

Amended translation: "The top of the lingula or fissure found in the middle of the larynx is seen in the tenth figure."

\section{H. MEANINGS OF WORDS}

The translator will expect to find in this text, as in any Latin text of this period, words which are not found, or are very rarely found, in classical Latin and words which, though common in classical Latin, are used in meanings which they did not have in classical Latin. The learning process mentioned earlier will include building up a list of these; Vesalius's synonymous pairs will sometimes be helpful in indicating new and unusual meanings. ${ }^{41}$ If the translator uses the classical rather than the later meaning of such words, the Latinless reader is likely to be left puzzled and wondering what Vesalius is getting at. Here are some examples from the portions translated by GH.

40) OLD s.v. obuius 4.

${ }^{41}$ Examples are sedes and simus: see section $\mathrm{F}$ of this article. 


\section{On translating Vesalius}

21. Latin 5516 of index (on the attachments of the hyoid): Tria ossicula, superioribus lateribus utrinque ut plurimum commissa.

GH 6 17: "Three ossicles, joined in the greatest degree to the upper sides."

Comment: The barely intelligible "joined in the greatest degree" is a mistranslation of this type. Even in classical Latin plurimum can mean "mostly" or "usually"; 42 and when Vesalius so uses it he often precedes it by ut "as", forming an adverbial phrase meaning "usually" or "most often". The phrase occurs again in the text of the chapter, where it makes a contrast with interdum "occasionally", "now and then". Compare also ut generatim "generally" (92 8). The reader might well be puzzled also by the reference to the "upper sides", despite GH's correct identification of these as the lesser horns (cornua minora). The point is that "side" is the classical meaning of latus; but with reference to the hyoid bone Vesalius uses it as a technical name for the horns, both lesser and greater. In our comment on passage 1 above we tried to indicate this new usage by putting "sides" in inverted commas; but it would be better to create a new term and translate "side-bones" or "laterals".

Amended translation: "Three ossicles, usually joined on either side to the upper laterals."

22. Latin 56 1-2 (on the muscles attached to the hyoid): Superiori enim sinui implantantur tertius et quartus huius ossis peculiares musculi: ad tuberis uero in hac sede conspicui latera, quae quodammodo in gibba sede sinuantur, insertionem tentant duo primi huic ossi peculiares musculi.

GH 8 9: "For on the upper depression are implanted the third and fourth peculiar muscles of this bone; clearly visible in this location near the sides of the protuberance which are somewhat hollowed in a bulging place, the first two particular muscles attempt their insertion into this bone."

Comment: "Attempt their insertion" is another such mistranslation. The verb tento is tempto in classical Latin; in classical Latin it does mean "attempt", but by Vesalius's time it had come to mean "achieve", and so simply "make". "We have here also an interesting example of Vesalius's liking for phrases that are bounded beginning and end by words that go together; here ad (preposition) governs latera (noun) and tuberis (noun) is described by conspicui (adjective), so that the phrase ad tuberis uero in hac sede conspicui latera "at the sides of the swelling visible in this area" is doubly tied together. The words duo primi huic ossi peculiares musculi "the first two muscles peculiar to this bone" are likewise a unit, bounded by an adjective (duo) and the noun it goes with (musculi).

Amended translation: "Into this upper depression are implanted the third and fourth muscles peculiar to this bone; the first two make their insertion into depressions to either side of the bulge apparent in this area."

23. Latin 15419 (on the arytenoid cartilage): . . et duabus constituatur cartilaginibus, ligamentorum duntaxat beneficio et laryngem succingentis membranae, inuicem admodum laxe commissis.

\footnotetext{
42 OLD s.v. b.

${ }^{43}$ Compare ch. 4 of Bk I (14 17), where he writes (of the type of joint he calls arthrodia): Quasi Natura hanc articulationis speciem in simplici articulo tentaret, ubi uix tantillum os moueri statuit "it is as if Nature
} 
GH 15 9: “. . . it is made up of two cartilages, albeit mutually somewhat loosely joined, thanks to the ligaments and the membrane surrounding the larynx."

Comment: "Albeit" mistranslates duntaxat, which is frequently used (as here) by Vesalius to mean "only". ${ }^{44}$ By Vesalius's time the classical meaning "thanks to" of beneficio + genitive 45 had become weakened to a simple instrumental "by means of" or simply "by". Inuicem, as in classical Latin, means "to each other" or "together". 46

Amended translation: “. . . it is made up of two cartilages somewhat loosely joined together only by ligaments and the membrane surrounding the larynx."

24. Latin 2573 (caption to figure 6): Sexta laryngem a reliquo asperae arteriae caudicis liberatam, ita posteriori facie exprimit, ut neque stomachi, neque communis alicuius musculi portionem adhuc reliquerim, interea tamen nullam laryngis cartilaginum sua sede dimouimus.

GH 18 8: "The sixth is the larynx freed from the rest of the stem of the rough artery, represented in its posterior surface so that I would leave out no portion of the gullet or of any common muscle, and at the same time we have removed no cartilage of the larynx from its place."

Comment: Having read GH's version one would expect to see the gullet and the common muscles in the illustration; but they are not there. This is not Vesalius's fault: it is a translation error. Relinquo here does not mean "leave out" (this meaning is usually the province of omitto or praetermitto); it means rather "I leave untouched", "I allow to remain". ${ }^{47}$ Hence this clause, with its double neque, lists things which have been cut away and do not appear in the figure, while the last clause, with adversative interea, ${ }^{48}$ lists the things that are still there. One must notice also that sexta (sc. figura) is the subject and laryngem the object of exprimit, and that, as ita ...ut introduces a consecutive clause, reliquerim is not potential.

Amended translation: "The sixth shows the back of the larynx freed from the rest of the stem of the rough artery, in such a way that I have included no part of either the gullet or any common muscle; but on the other hand I have removed none of the laryngeal cartilages from its place."

25. Latin 285 (385) 1 (on the external jugular vein-not the internal jugular as in $\mathrm{GH}$ ): Portio interiora oris subiens, in primis suis scissionibus glandulas exigit quae...

GH 30 1: "The portion entering the inner part of the face, in its first divisions bypasses the glandules which..."

Comment: Vesalius does not say that this vein bypasses the lymph nodes but that

constructed this type of articulation in a simple joint where she had decided that the bone should move scarcely at all". So also at 156 1-2 sectionem tentare means "to make a cut". Vesalius uses molior in a similar meaning, which this verb already possessed in classical Latin (OLD s.v. 4).

${ }^{44}$ Duntaxat may have this meaning in classical Latin (OLD s.v. 2).

45 OLD s.v. beneficium 4.

${ }^{46}$ OLD s.v. 2, 3.

47 OLD s.v. 11.

${ }^{48}$ OLD s.v. b; Vesalius uses interim similarly. 


\section{On translating Vesalius}

they grow out from it: exigo even in classical Latin could mean "send out". 49 Vesalius constantly uses it of a part of the body from which some other part grows out. So he writes in chapter 11 of Book I (64 15) occipitii os ... utrinque unum exigit capitulum "the occipital bone ... puts out a small head ${ }^{50}$ on each side".

Amended translation: "The portion entering the inner part of the face, in its first divisions puts forth glandules which..."

26. Latin 301 (401) 11 (on the common carotid): . . in duos disscinditur ramos, quorum grandior idemque interior fauces subit, ac mox laryngi et linguae propagines deriuans, ad caluariae basim properat ...

GH $3014:$ “. . . it is split into two branches, the larger and inner of which enters the pharynx, and soon forming branches of the larynx and tongue, proceeds to the base of the skull ..."

Comment: The Latin verb deriuo is the source of English "derive"; but even in classical Latin it occasionally meant "pass on", 51 and Vesalius uses it here and elsewhere to mean "send out". In this meaning it takes the dative of the recipient, supplied here by laryngi et linguae "to the larynx and tongue". For fauces = "throat" see passage 2 above.

Amended translation: ". . . it splits into two branches, the larger and inner of which enters the throat, and soon sending out branches to the larynx and tongue, proceeds to the base of the skull..."

27. Latin 327 (427) 2 of ch. 9 (on the vagus nerve): . . nullum aeque sparsam ramorum edit sobolem, neque in tam multas easdemque uarias inseritur partes...

GH 30 18: “. . . no pair puts out a shoot so sparse of branches, or is introduced into so many and various places".

Comment: The contradiction between "sparse" and "so many and varied" is only in the translation. Latin sparsus means "widely scattered",52 it only sometimes has the connotations of its English derivative "sparse". Ramorum depends on sobolem and is genitive of material. We notice here again Vesalius's tendency to say the same thing in two different ways: the words after neque repeat the idea of sparsam.

Amended translation: “. . no pair puts out so widely scattered an offspring of branches, or is introduced into so many and various places".

\section{MISCELLANEOUS}

We now offer three further instances in which inadequacies of translation have inhibited a proper understanding of Vesalius's knowledge of human anatomy.

28. Latin 327 (427) 13 of ch. 9 (on the vagus nerve): Deinde sextum par quum hanc assciuit portionem, laryngis musculis ramulos transuersim exhibet. Sunt autem illi musculi

\footnotetext{
${ }^{49}$ OLD s.v. exigo 4. In De fabrica the noun sinus "depression" may (in the accusative case) be the direct object of exigo (139 53), which suggests that this verb should be regarded as a member of the cell meaning "possess" (note 21 above).

50 Occipital condyle.

51 OLD s.v. $1 \mathrm{~b}$ ad fin.

52 Compare OLD s.v. spargo 3.
} 


\section{W. F. Richardson and J. B. Carman}

duo scutum imitanti laryngis cartilagini duntaxat proprii, qui ex stomacho gulaeue posteriori sede pronati eius cartilaginis lateribus inseruntur. deinde duo tertiae cartilaginis basim occupantes, et duo ex illis qui primam cartilaginem secundae committunt.

GH 32 14: "Then, when the sixth pair has taken on this portion, it displays little branches transversely on the muscles of the larynx. There are also those two muscles just near the cartilage that resembles a shield, that originate from the gullet and the posterior seat of the throat and are inserted in the sides of this cartilage; then the two occupying the base of the third cartilage, and two of those that join the first cartilage to the second."

Comment: Here the translators have failed to recognize that the second sentence specifies the muscles alluded to in the first sentence. The first two of them are the constrictores pharyngis inferiores, which Vesalius counts as numbers 5 and 6 of the common (extrinsic) muscles of the larynx. It is therefore disconcerting here to find Vesalius calling them proprii, for this is the adjective which he used many times in Book II chapters 21 and 22 to mean "intrinsic" as opposed to "common" or "shared" (i.e. extrinsic). Recognizing this problem, GH have here translated proprii as "just near", a translation which seems to us indefensible on any grounds. In fact the two contexts are not the same. In II 21 and 22 Vesalius is talking about the larynx as a whole, to which certain muscles are proprii "intrinsic"; here he is talking only about the thyroid cartilage, and proprii has its normal and regular sense "belonging to", 53 without the technical notion of "intrinsic" as applied to certain muscles of the larynx as a whole. It may be remarked that Vesalius has a large cell containing words for "send out"; exhibeo ${ }^{54}$ is one of these (as also are dispenso and deriuo in the previous example). Musculis, like glandulis in the previous example, is dative ("to") with the verb of sending.

Amended translation: "Then, when the sixth pair has taken on this portion, it sends out little branches transversely to muscles of the larynx. These muscles are: the only two belonging to the cartilage resembling a shield that originate from the gullet and the back of the throat and are inserted into the sides of this cartilage; the two occupying the base of the third cartilage; and two of those that join the first cartilage to the second".

29. Latin 328 (428) 12 of text (on the recurrent laryngeal nerves): Sinister itaque sexti paris neruus iam in thoracis cauitatem ingressus, arteriae in sinistram manum propagatae ramulos, qui sursum reflecterentur, exporrigere nequit, quod ea oblique sursum, non autem dextrae arteriae modo, transuersim, in alam contendat. Haudquaquam enim aeque tuta ad obliquum atque transuersum, chordae alicuius reflexus perficitur. immo haec si ad obliquum baculum reuoluitur, sensim sursum conscendit, eandem reflexus sedem nunquam seruans: ac proinde sinister neruus tantisper uersus cordis basim descendit, quousque extra cordis inuolucrum arteriae magnae contingat truncum, qui deorsum ad spinam explicatur.

GH 33 17: "The left nerve of the sixth pair, now having entered the cavity of the thorax, is unable to extend the branches of the artery propagated into the left hand so that they are bent back upwards because the artery runs to the armpit obliquely upwards, not

53 OLD s.v. proprius 2.

${ }^{54}$ Cf. OLD s.v. 1. 


\section{On translating Vesalius}

transversely in the manner of the right artery. For the turning back of any nerve is in no way as safely accomplished on the oblique as it is on the transverse; indeed, if it is turned back toward the oblique rod [arteria subclavia sinister] it gradually climbs upward, the turning point never keeping the same place; and the more the left nerve descends all the time to the base of the heart, the more it touches the trunk of the great artery outside the envelope of the heart, which is extended downward toward the spine."

Comment: In the first sentence here we have another member of the "send out" cell, exporrigere; it governs the dative arteriae ("to the artery"), which is therefore not genitive ("of") with ramulos "little branches". But the main point here is the second sentence, which is not a description of any nerve or artery/vein but offers the analogy of a chord (chorda) winding round a stick (baculum); the analogy is marked by the explanatory enim at the beginning of the sentence. GH's identification of the oblique rod as arteria subclavia sinister must therefore go. In this Latin sentence the noun reflexus occurs twice; the first time it is nominative (subject of perficitur) and the second gentive (depending on sedem). We notice also the contrast between transuersus "horizontal" (i.e. "at right angles") and obliquus "oblique" ("not at right angles"). ${ }^{55}$ The words ac proinde mark the end of the analogy and the point where Vesalius returns to his description of the left recurrent laryngeal nerve. In this last part the words tantisper . . quousque mean "until"; Vesalius uses the same expression elsewhere in the work. ${ }^{56}$

Amended translation: "The left nerve of the sixth pair, having now entered the cavity of the thorax, is unable to send out to the artery which travels to the left hand branches which could wind upwards, because the artery runs to the armpit obliquely upwards, not transversely in the manner of the right artery. The bending of a cord cannot be made as securely around an oblique as around a transverse object; if it turns around an oblique stick it gradually climbs upward and does not maintain the same point of turning. And so the left nerve descends towards the base of the heart until, outside the envelope of the heart, it reaches the trunk of the great artery which is extended downward toward the spine."

30. Latin 330 (430) 2 of ch. 10 (on the hypoglossal nerve): incipit enim aliquot inuicem distantibus surculis, a dorsali medulla, ubi modo caluariam est egressura.

GH 34 21: "for it starts out from the twigs that stand somewhat apart from each other, from the dorsal medulla where it has just left the skull."

Comment: Despite the translation, Vesalius was well aware that the hypoglossal nerve commences within the skull: egressura is future participle, not past, and est egressura means "is about to leave", not "has just left". 57 The translators have also omitted aliquot: these are not "the twigs" but "a number of twigs". Furthermore, surculis is ablative of the instrument ("by means of a number of twigs"), not of separation ("from"), the source being expressed here, as usual, by $a+$ ablative. ${ }^{58}$

Amended translation: "for it starts out, by means of a set of twigs standing somewhat apart from each other, from the dorsal marrow where this is about to leave the skull."

\footnotetext{
55 See note 23 above.

st See 56 15; tantisper... dum and tantisper... donec also appear. See note 35 above.

${ }^{57}$ For the transitive use of this verb see OLD s.v. egredior 4.

${ }^{58}$ Similarly at 13018 principio is ablative of instrument and the source is expressed as ex . . amplitudine: "[the iliacus muscle] grows forth from this area inside the ilium by means of a broad and fleshy attachment."
} 


\section{J. ENVOI}

In conclusion we may add that there are various passing references to the laryngeal muscles in chapters 2 and 3 of Book II, where Vesalius discusses the form and structure of muscles in general. The following from chapter $2(22249)$ is representative.

31. Latin: Breues enim tendine carent, et undique carnosi sunt, ut laryngis omnes, si duos rectos exceperis, quatuor tertiam cartilaginem primae iungentium, illi enim in insertione nerueam naturam obscure exprimunt.

Translation: "Short muscles have no tendon and are fleshy throughout; for example, all those of the larynx except the two vertical ones of the four which join the third cartilage to the first [actually second], for these show a vaguely sinewy nature at their insertion."

Comment: Here once again is quatuor as genitive plural (with iungentium): compare passage 4 above, which also supplies the evidence that Vesalius's "first" here is a mistake for "second". 